\title{
Justifying Limitations on the Freedom of Expression
}

\author{
Gehan Gunatilleke $^{1,2}$
}

Accepted: 26 October 2020/ Published online: 1 November 2020

(C) The Author(s) 2020

\begin{abstract}
The freedom of expression is vital to our ability to convey opinions, convictions, and beliefs, and to meaningfully participate in democracy. The state may, however, 'limit' the freedom of expression on certain grounds, such as national security, public order, public health, and public morals. Examples from around the world show that the freedom of individuals to express their opinions, convictions, and beliefs is often imperilled when states are not required to meet a substantial justificatory burden when limiting such freedom. This article critiques one of the common justificatory approaches employed in a number of jurisdictions to frame the state's burden to justify limitations on the freedom of expression - the proportionality test. It presents a case for an alternative approach that builds on the merits and addresses some of the weaknesses of a typical proportionality test. This alternative may be called a 'duty-based' justificatory approach because it requires the state to demonstrate - through the presentation of publicly justifiable reasons - that the individual concerned owes others a duty of justice to refrain from the expressive conduct in question. The article explains how this approach is more normatively compelling than a typical proportionality test. It also illustrates how such an approach can better constrain the state's ability to advance majoritarian interests or offload its positive obligations by limiting the freedom of expression of minorities and dissenting voices.
\end{abstract}

Keywords Freedom of expression · Liberty $\cdot$ Limitations on rights · Duties of justice $\cdot$ State authority $\cdot$ Justification $\cdot$ Public reason

\section{Introduction}

The freedom of expression is vital to our ability to convey opinions, convictions, and beliefs, and to meaningfully participate in democracy. The state may, however, 'limit'

Gehan Gunatilleke

ggunatilleke@law.harvard.edu

1 Harvard Law School, Cambridge, MA, USA

2 University of Oxford, Oxford, UK 
the freedom of expression for certain reasons. International and domestic law empowers the state to impose limitations on the freedom of expression in order to advance broad aims such as national security, public order, public health, and public morals. Yet cases from around the world demonstrate that the freedom of expression is vulnerable to unwarranted restrictions.

One of the most common tests used to determine whether a limitation on the freedom of expression is justified has come to be known as the 'proportionality test'. In this article, I critique the typical proportionality test that is applied in many jurisdictions. I then offer a justificatory approach that reframes this typical test to address some of its normative and practical weaknesses. This alternative approach places individual 'duties of justice' at the heart of the state's burden to justify a limitation on the freedom of expression.

The first section of this article discusses the unique place that the freedom of expression occupies in the liberal tradition, and explains why a robust justificatory approach is needed to protect the freedom of expression from unwarranted limitations. The second section explores some of the main weaknesses of a typical proportionality test when applied in relation to limitations on the freedom of expression. I take examples from a number of countries to illustrate the recurring tendency for the freedom of expression to be subjected to unwarranted restrictions. In the final section, I make a case for a 'duty-based' justificatory approach. The approach would require the state to demonstrate - by presenting publicly justifiable reasons - that the individual concerned owes others a duty of justice to refrain from the expressive conduct in question. I explain how this approach addresses some of the normative weaknesses of a typical proportionality test. I will also illustrate how such an approach can better deal with the state's ability to advance majoritarian interests or offload its positive obligations by limiting the freedom of expression of minorities and dissenting voices.

\section{The Value of the Freedom of Expression}

The freedom of expression broadly involves the communication of ideas, opinions, convictions, beliefs, and information. International legal instruments such as the International Covenant on Civil and Political Rights (ICCPR) recognise the 'freedom of expression' as a right that can be exercised 'either orally, in writing or in print, in the form of art, or through any other media of [the individual's] choice' (art 19, para 2).

Taking the freedom of expression seriously involves acknowledging it both as a 'liberty' and a 'claim right'. A 'liberty', conceptually speaking, refers to the absence of any competing duty to do or refrain from doing something (Hohfeld 1919, pp. 36-39). ${ }^{1}$ The freedom of expression is a liberty, as it involves absence of constraints on what an individual is free to express. For example, a person may have the liberty to advocate for a country's ratification of the ICCPR, as there may be no competing duty owed to others to refrain from such advocacy. A 'claim right' meanwhile corresponds to another's duty to do or refrain from doing something (Hohfeld 1919, p. 39; see also

\footnotetext{
${ }^{1}$ Wesley Hohfeld's reference to liberty (what he called 'privilege') appears to be analogous to Isaiah Berlin's conception of 'negative liberty', which he describes as the area within which a person 'is or should be left to do or be what he is able to do or be, without interference' (Berlin 1969, p. 2)
} 
George 1995, pp. 119-122). The normative significance of a 'right' is that it is in some way claimable (O’Neill 1996, p. 131; Hart 1955), i.e. that the rights-holder has an entitlement to claim, from duty-bearers, the performance of duties (Feinberg 1970, p. 243). The freedom of expression entails 'claim rights', including the claim right to noninterference with the expression in question. Since claim rights correspond to duties, the freedom of expression imposes duties on others to refrain from interfering with the expression in question. For example, an individual's claim right to advocate for the election of a particular candidate contemplates the imposition of duties on others, including the state, to refrain from interfering with such advocacy.

The reason we recognise certain claimable rights is often linked to the underlying interests these rights set out to protect. Joseph Raz observes a person has a 'right' when his interests are sufficient reason for holding others to be under a duty ( $\operatorname{Raz} 1986$, p. 166). The importance of the interests that underlie the freedom of expression point to why we ought to, and indeed do, recognise it as a claimable right. Recalling such value is important, as the process through which we justify limitations on the freedom of expression is contingent on the value we attach to it.

On the one hand, the freedom of expression is of inherent value to the individual, as it involves the external communication of an individual's 'forum internum' or inner realm of thoughts, beliefs, and convictions - a realm that is arguably inviolable (Boyle and Shah 2014, p. 226). The freedom of expression is then connected to certain foundational values associated with the forum internum, such as personal autonomy and human dignity. On the other hand, the freedom of expression has consequentialist and epistemic value. It is certainly valuable to democracy, as political participation, criticism of government, media freedom, and indeed the very act of voting are aspects of the freedom of expression. John Stuart Mill's defence of the freedom of expression points to its epistemic value. Mill argues that human fallibility justifies greater tolerance of the freedom of expression, as there can be no certainty with respect to what is true and what is false (Mill 1859, pp. 19-21). He contends that there is no inherent justification for suppressing the beliefs and opinions of others through coercive means, even if one believes that those beliefs and opinions are untrue, as they may in fact be true, and the alternative beliefs and opinions untrue. Mill also claims that truth can only be ascertained in a 'clearer' and 'livelier' form when it is permitted to collide with error (p. 19), and adds that 'conflicting doctrines' often 'share the truth between them' (p. 44).

The inherent, consequentialist, and epistemic value of the freedom of expression suggests that it should not be limited without meeting a substantial burden of justification. When the conduct in question relates to the freedom of expression, this justificatory burden falls on those who wish to restrict the conduct. Such a scheme is consistently featured in the liberal tradition, and is consistent with the 'fundamental liberal principle' (Gaus 1996a, pp. 162-166) - that freedom is the norm and the limitation is the exception; so 'the onus of justification is on those who would use coercion to limit freedom' (Gaus 1996b; Feinberg 1987, p. 9). Therefore, in the case of the freedom of expression, the starting point in the process of reasoning is clear: an individual is ordinarily entitled to engage in the conduct associated with the freedom of expression, unless a restriction on the conduct is carefully and convincingly justified. 


\section{The Proportionality Test}

Justification involves providing good reasons for an action, omission, or belief. According to Raz, a reason is 'a consideration in favour of doing, believing, or feeling something' (Raz 1999, pp. 16-17; see also Scanlon 1998, p. 17). Given the special value we attach to the freedom of expression, a reason must be of a particular kind when deployed to limit the freedom of expression. I accordingly approximate good reasons - in the specific context of justifying limitations on the freedom of expression - to what John Rawls called 'public reason' (Rawls 2005, pp. 212-254). Rawls explains that 'public reason' entails the justification of political decisions through the use of values and standards that are publicly available and acceptable (pp. 227-228). Reasons can be characterised as 'public' when citizens who are equal accept them as valid (p. 213). Crucially, a reason does not fall within the rubric of public reason merely because the majority in society view it as a good reason. Even if, for instance, the overwhelming majority view some minority group as 'culturally inferior', public reason would exclude such inferiority as a justification for discriminating that group. It would be excluded because such perceived inferiority is not a reason that is publicly available and acceptable to all citizens on the basis of equal citizenship. Therefore, ideals of equality are imbedded into the concept of public reason; Equality is a constituent element that necessarily excludes purely majoritarian reasoning.

In this section, I examine one of the 'prominent' approaches (Möller 2014, p. 32) to justifying limitations on the freedom of expression: the proportionality test. I aim to explain the typical features of this test, and point to some of its main weaknesses, particularly when applied to limitations on the freedom of expression.

A typical proportionality test assesses whether a limitation on a right can be 'justified by reference to gains on some other interest or value' (Urbina 2014, p. 173). Most jurisdictions in Europe, and treaty bodies such as the United Nations Human Rights Committee, apply the proportionality test when evaluating the permissibility of limitations. The test usually contains four limbs (Tridimas 2007, p. 139). First, the state must pursue an aim that serves a 'compelling' (Kumm 2004, p. 593) or 'legitimate' interest (Tremblay 2014, p. 865; Barak 2012) when limiting the right. This limb contains a normative requirement, as certain interests that are 'illegitimate' would not be permissible at the outset. For example, the aim to destroy a population would not qualify as 'legitimate'. Second, there must be a rational nexus between the specific measure used to limit the right and the legitimate interest. This limb is sometime referred to as the 'suitability test' (Arai-Takahashi 2005, p. 32; Van Dijk and Van Hoof 1998: pp. 771-773). Third, this measure must be necessary to advancing, or preventing setbacks to, that legitimate interest. This limb is naturally termed the necessity test. Finally, the measure must be, in the 'strict sense', proportionate, i.e. it must involve a net gain, when the reduction in the enjoyment of the right is weighed against the level to which the interest is advanced (Rivers 2006, p. 181). According to Aharon Barak, proportionality stricto sensu 'requires a balancing of the benefits gained by the public and the harm caused to the...right through the use of the means selected by law to obtain the proper purpose' (Barak 2012, p. 340). Grégoire Webber meanwhile notes that such 'balancing' is designed to demonstrate a 'proportionality' between the negative effect (on the freedom of expression, for instance) on the one hand, 
and the beneficial effect of the limitation (in terms of the legitimate interest) on the other hand (Webber 2009, pp. 71-72).

Different versions of the proportionality test have been applied in different jurisdictions. The German Federal Constitutional Court, for instance, applies a four-part test that considers the question of 'balancing' only in the final stage of the test. This version of the test has come to reflect a general rule of law within European Community law (Arai-Takahashi 2005, p. 29). By contrast, the Canadian Supreme Court considers 'balancing' at earlier stages as well, i.e. under the legitimacy and necessity subtests (Grimm 2007). The Court has found that, under the legitimacy subtest, the legitimate interest must be of sufficient importance to warrant overriding the right in question ( $\mathrm{R}$ v. Oakes 1986; Choudhry 2006). Moreover, under the necessity subtest, the selected measure must, when compared to the available alternatives, impair the right the least. Accordingly, the Canadian version of the test expects some balancing to be undertaken when determining which aims are legitimate for the purpose of justifying a limitation, and when determining whether the measure in question is the least restrictive among available options. Meanwhile, in the United States (U.S.), 'content-based' limitations on the freedom of expression attract 'strict scrutiny', i.e. the highest level of judicial scrutiny of the restrictive measure. This approach is essentially founded on an American common law idea that the right to the freedom of expression-protected under the First Amendment to the United States Constitution - is a highly valued individual right (Strauss 2002). In the U.S., the state must accordingly meet the heaviest justificatory burden when restricting certain types of speech, such as political speech. By contrast, 'content-neutral' limitations on the freedom of expression (for example, restrictions on the form, extent, timing, or medium of the expression in question) are reviewed under a 'intermediate scrutiny' test. The U.S. Supreme Court formulated a four-part test to determine whether a content-neutral limitation is constitutional (United States v. O’Brien 1968; see also Zoller 2009, p. 906; Stone 1987): (1) the limitation must be within the constitutional power of government; (2) the limitation must further an important or substantial governmental interest; (3) the governmental interest must be unrelated to the suppression of the freedom of expression; and (4) the limitation must be narrowly tailored - no greater than necessary. In subsequent cases, the Supreme Court devised a fifth limb: the limitation must leave open ample opportunity for communication (Ladue v. Gilleo 1994). Although the justificatory approach prevalent in the U.S. is rarely termed a 'proportionality test', it clearly contains elements of balancing. Whichever version of the test is employed, it is apparent that the proportionality test generally involves a justificatory burden of a particular form: the limitation on the freedom of expression is justified only if the countervailing interests outweigh the individual's interests in the freedom of expression. It is for this reason that the very notion of proportionality is described as 'inevitably flexible and open-textured in nature' (Arai-Takahashi 2005, p. 34).

A typical proportionality test has a number of weaknesses worth noting. There is an ongoing scholarly debate on the suitability of the test, and in the course of discussing some of the weaknesses I detect in the typical version of the test, I shall touch on some of the elements of this debate. Of course, proponents of proportionality often argue that the weaknesses pointed out by critics are with respect to cases in which the test is misapplied, and that the proportionality test is sound if it is applied correctly (e.g. Möller 2014; Kumm 2010). However, the strength of the test lies in how it is applied in 
practice. In this context, I set out to evaluate the 'typical' proportionality test, which contains both normative and political weaknesses when applied to assess limitations on the freedom of expression. In doing so, I leave open the potential for the test to be applied in a more robust manner. In fact, my proposal conceives of a more robust version of the test.

At a normative level, the typical test often fails to adequately recognise and account for the special value of the freedom of expression. Such a weakness is particularly evident where the court or tribunal concerned glosses over the first three limbs of the test and focuses instead on the final stage of balancing. Kai Möller, referring to German practice in particular, observes that typically, 'the balancing stage dominates the legal analysis and is usually determinative of the outcome' of the assessment of whether a limitation is permissible or not (Möller 2014, p. 34). When the emphasis of the assessment is on balancing alone, the court or tribunal would often rely on practical reasoning to determine the permissibility of a limitation (Kumm 2010, p. 147). It is for this reason that many rights scholars have criticised the proportionality test for its failure to give adequate normative weight to individual rights (Letsas 2007; Tsakyrakis 2009). According to these critics, proportionality treats rights on par with any other interest or value, and such an equation undermines the special importance we attach to rights. Many of these critics rely on well-known 'rights-based' approaches to justifying limitations on rights, such as the approaches advocated by Ronald Dworkin and John Rawls. According to Dworkin, individual rights, such as the right to the freedom of expression, 'trump' other non-rights interests (Dworkin 1977, p. xi). He argues that non-rights interests, such as collective interests, should be ruled out when justifying limitations on individual rights (Dworkin 1984, p. 153; see also Waldron 1993, p. 210). This approach is based on the view that rights have peremptory value; they exist, and ought to be protected, even if the community is genuinely worse off due to their existence or protection (Dworkin 1985, p. 350). Understood this way, the right to the freedom of expression constrains the state's pursuit of collective interests, and sets out a protected realm that the state cannot interfere with even when collective interests could be served through such interference. Rawls meanwhile argues that basic liberties, such as the freedom of expression, can only be limited for its own sake or for the sake of other basic liberties (Rawls 1999, p. 220). These basic liberties have 'lexical priority"2 over all other types of interests. Accordingly, basic liberties such as the freedom of expression would have 'absolute weight' with respect to interests unrelated to basic liberties (Rawls 2005, p. 294). For example, the freedom of expression cannot be denied to an individual on grounds such as 'economic efficiency and growth' (pp. 294 295). Therefore, all reasons that are not related to basic liberties of similar importance to the freedom of expression will be excluded (at the outset) from the justificatory process. In sharp contrast to these rights-based approaches, the proportionality test expects a court or tribunal to weigh rights such as the right to the freedom of expression with collective interests such as national security, or public order, health, or morals. Such weighing - it could be argued - places the freedom of expression on the same normative plane as these collective interests, thereby undermining its peremptory value.

\footnotetext{
2 'Lexical priority' typically refers to the order in which values or principles are prioritised. Rawls argued that basic liberties, such as the freedom of expression, had lexical priority over other interests.
} 
This normative challenge is strongly linked to the textual framework of many international and domestic instruments that set out the basis for limiting the freedom of expression. For example, article 19, paragraph 2 of the ICCPR, and article 10, paragraph 2 of the European Convention on Human Rights (ECHR), explicitly permit states to limit the freedom of expression on the grounds of collective interests, such as public order and public health. Similarly, the constitutions of numerous countries permit limitations on the freedom of expression on the basis of a host of collective interests. The challenge may then also be doctrinal, as the typical proportionality test often suffers from normative weaknesses essentially because the legal doctrine that sets out the test reflects these weaknesses. Accordingly, the ICCPR and the ECHR can encounter normative problems in practice, as the limitation regimes found in these instruments contemplate broad governmental discretion when imposing limitations on the freedom of expression. Such discretion has raised serious concerns among scholars with respect to how well proportionality meets normative priorities such as the rule of law, or legal predictability (Von Bernstorff 2014, p. 66; Urbina 2014, p. 180).

At a political level, a typical proportionality test is vulnerable to two risks associated with granting the state wide discretion to limit the freedom of expression. First, the state can use a limitation regime to advance majoritarian interests. The freedom of expression of minorities and political dissenters may be targeted for reasons that are not publicly justifiable. In this context, majoritarian interests can infiltrate limitation grounds such as national security, public order, public health, and public morals. Second, the state can, in the course of limiting an individual's freedom of expression, attempt to offload its own positive obligations owed to society. An individual's expressive conduct can appear to 'cause' others to react in ways that harm third parties. Such cases often arise when the expressive conduct has a religious dimension. Although the expressive conduct may also be classified as religious manifestation or practice, it is difficult to exclude such conduct from the broader domain of the freedom of expression. In such cases, the state may choose to restrict the specific expressive conduct rather than focus on the wrongdoers who engage in violence. It is the state that owes citizens a positive obligation to maintain law and order, and it is up to the state to prevent violence, and punish those who engage in it for whatever cause. However, when the violence is committed by members of the majority community, the state may look to target the individual whose conduct appeared to 'cause' the wrongdoing, rather than risk confronting the majority community. In such circumstances, it may attempt to justify a restriction on the expressive conduct of the individual concerned, ostensibly to maintain public order and protect citizens from the violent reactions of others. It may do so regardless of how unreasonable such reactions are.

The typical proportionality test has no convincing answer to the political risks associated with state authority to limit the freedom of expression. It relies heavily on the good faith of the state, and the ability of a court or tribunal to convincingly weigh the competing interests at stake. Yet several examples from a variety of jurisdictions demonstrate that courts and tribunals are often compelled to offer the state wide discretion. The proportionality test only requires the adjudicative body to assess which of the two interests - the individual's interest in the freedom of expression or the legitimate interest being pursued by the state - is weightier. It would not contemplate any specific threshold that signals that the competing interest is sufficiently weighty. Scholars such as Francisco Urbina accordingly point out that the incommensurability of 
competing values and interests makes the proportionality test unsuited to determining the permissibility of limitations on rights (Urbina 2015). Given that it is so difficult to undertake the task of balancing with any precision, the adjudicative body would often defer to the state.

A number of illustrations demonstrate both the normative and political weaknesses inherent in a typical application of the proportionality test. Admittedly, some of these cases overlap with the terrain of other rights, such as the freedom of religion or belief. Yet the point about the freedom of expression is that it is a general core right that underlies many other rights. The inherent weaknesses of the typical proportionality test are best observed precisely in these complex cases where several rights are at play. Three classes of cases may be briefly cited to illustrate the weaknesses I am referring to.

First, the state may rely on majoritarian conceptions of morality to restrict certain expressions deemed contrary to those conceptions. The classic example of such restrictions on the freedom of expression is the landmark case of the European Court of Human Rights, Handyside v. The United Kingdom (1976). In this case, the Court upheld the seizure of an educational book that dealt with the subject of sex, and found no violation of the freedom of expression in terms of article 10 of the ECHR. The limitation was justified on the basis of public morals. A similar example is the restriction of the advocacy of same-sex rights in Russia. In Fedotova v. The Russian Federation (2012), the complainant displayed posters that read 'homosexuality is normal' and 'I am proud of my homosexuality'. The posters were displayed near a secondary school. The complainant claimed that the purpose of the expression was to promote tolerance towards gay and lesbian individuals. She was convicted of public actions aimed at 'propaganda of homosexuality' among minors. The state asserted that the conviction was necessary in the interests of children 'to protect them from the factors that could negatively impact their...moral development' (para 5.6 of the Decision of the Human Rights Committee). The Human Rights Committee relied on the principle of non-discrimination, and found that the limitation was discriminatory on the basis of sexual orientation. It did not actually apply a typical proportionality test to deal with the limitation, and instead relied on an additional normative basis to find a violation of the freedom of expression. The case serves as a reminder that a typical proportionality test would only require the balancing of the individual's interests in the freedom of expression with the asserted public interest in morality and moral development. Such a test would not account for the fact that the asserted interest in public morals is actually a majoritarian - for instance, heteronormative - conception of morality. The typical test would need to be bolstered to deal with the challenge. The Committee accordingly bolstered the test by relying on the principle of non-discrimination. However, if a more general prohibition on expressions about sex had been instituted, such as, for example, the censoring of a book dealing with sex education, the Committee's reliance on the principle of non-discrimination alone would not have sufficed.

Second, the state may rely on majority values and interests to restrict certain types of expressions deemed a threat to these values and interests. The jurisprudence of the European Court of Human Rights offers a number of examples of such restrictions. In these cases, the doctrine set out in the text of article 10 of the ECHR has governed the Court's reasoning. The Court has typically applied a four-part test: the limitation must (1) be provided by law; (2) pursue a legitimate aim listed in the article; (3) be necessary 
in a democratic society; and (4) be proportionate stricto sensu. Some proponents of the proportionality test adopted by the European Court of Human Rights have suggested that the phrase 'necessary in a democratic society' entails a commitment to pluralism, and is a check on majoritarianism (Zysset 2019, p. 235). Indeed, the Court has viewed certain aspects of the freedom of expression, such as press freedom, and the criticism of public officials, as vital due to their relevance to the democratic process. It has accordingly placed a heavy justificatory burden on the state when expressive conduct associated with 'democracy' is being restricted (Thoma v. Luxembourg 2001). Yet, this counter-majoritarian check is not always evident in the Court's jurisprudence, particularly when the religious sentiments of the majority community are at stake. In the case of İ.A. v. Turkey (2005), the managing director of a publishing house was convicted of blasphemy for publishing a novel that was deemed deeply offensive to Muslims. The applicant complained that the conviction violated his freedom of expression under article 10 of the ECHR. In response, the state argued that 'the criticism of Islam in the book had fallen short of the level of responsibility to be expected of criticism in a country where the majority of the population were Muslim' (para. 20 of the judgement). Accordingly, the Court was called upon to weigh the individual's freedom of expression with the majority community's interests in their own freedom of thought, conscience, and religion. The majority of the Court held that the novel contained statements that amounted to 'an abusive attack on the Prophet of Islam' (para. 29). It concluded that the restriction was reasonable, as it 'intended to provide protection against offensive attacks on matters regarded as sacred by Muslims' (para. 30). It accordingly found that there was no violation of article 10, and that the measures under consideration satisfied the proportionality test.

The European Court's observations in İ.A. v. Turkey relied heavily on the doctrine of margin of appreciation, which is often applied to afford states some 'latitude' when limiting rights (Arai-Takahashi 2002, p. 2). The doctrine was applied in the case of Handyside v. the United Kingdom (1976), and has since been relied upon to justify some level of judicial deference to states on questions of limitations. For example, in Otto-Preminger-Institut v. Austria (1995) and in Wingrove v. The United Kingdom (1996), the Court relied on the margin of appreciation doctrine to hold that the restriction of expressions that caused public offence to the majority religious group (in both cases the majority group was Christian) was permissible under the ECHR. In each case, the Court found no violation of article 10 of the ECHR, and held that the restrictions on the public screening of films deemed offensive to a religious majority were proportionate.

The margin of appreciation doctrine has also been applied in cases involving religious expression, including wearing certain religious attire. Cases such as S.A.S v. France (2014) and Leyla Șahin v. Turkey (2005) essentially concerned article 9 of the ECHR, which protects the freedom to manifest religion or belief. However, the applicants in both cases also claimed that the limitations in question violated their freedom of expression under article 10. The Court upheld restrictions on the niqāb (a full-face veil) and the Islamic headscarf on the basis that such attire is incompatible with 'European' values such as 'living together' and 'secularism', and found that these restrictions did not violate article 10 of the ECHR. In such cases, the Court has sought to balance the individual's right to the freedom of expression (including the freedom to engage in certain types of religious expression) with broader societal aims such as 
secularism, and has held that the limitations in question were proportionate. In each case, the Court has relied on the margin of appreciation doctrine to evaluate the permissibility of the limitation on the freedom of expression. The doctrine has thus attracted intense criticism from scholars - primarily due to the fact that the Court has often lacked a coherent and consistent approach to applying the doctrine (Letsas 2006).

Third, the state may rely on broad conceptions of 'public order' to restrict expressions that may 'cause' others to react in a violent or disorderly manner. In the case of Zaheeruddin v. State (1993), the Pakistani Supreme Court speculated that the public expressions of the Ahmadi community claiming that they are 'Muslim' would provoke outrage among the Sunni majority (Khan 2015). It therefore justified restricting the public display of the Kalimah ${ }^{3}$ on the basis of public order. The Human Rights Committee has also considered cases involving limitations on the freedom of expression on the basis that the expression in question could cause others to engage in disruptive conduct. In Claudia Andrea Marchant Reyes et al. v. Chile (2017), the Committee considered the removal and destruction of a work of art on the grounds of 'public order'. The work of art contained fifteen banners commemorating the fortieth anniversary of the military coup d'état in Chile. The complainant had in fact obtained the necessary approvals to display the banners at nine bridges. The state, however, argued that the removal of the banners was necessary to prevent 'potential disruption to public order arising out of the burning of the banners', and that it was the state's 'duty' to safeguard public order. It argued that the limitation was for the 'benefit of persons who crossed the bridges in question on a daily basis, given that the banners could have been burned precisely at the times of the greatest movement of people and caused injury' (para 4.3 of the Committee's decision). In this particular case, the Committee found that the limitation was unwarranted, as the state provided 'no evidence of what specific information it had that gave rise to fears that the work might be burned' (para 7.5). Its decision may have been different if in fact there was such evidence. In any event, the case remains a good example of how the state may seek to offload its obligation (to maintain public order) onto the individual concerned by limiting the individual's freedom of expression - a vulnerability to which the typical proportionality test has no coherent response.

Majoritarian conceptions of certain public interests, including public order and morals, often drive the state's justification for a limitation on the freedom of expression. The state can also offload its positive obligations to maintain public order in the course of limiting an individual's freedom of expression, and seek to justify restrictions on expressions that attract majority outrage. These types of justifications can infiltrate the reasoning of the court or tribunal tasked with assessing the proportionality of the limitation. In essence, the typical proportionality test, which asks the adjudicative body to do no more than weigh competing interests, does not avoid these political risks. In the final section of this article, I present an alternative justificatory approach that attempts to build on the merits, and address the weaknesses, of a typical proportionality test.

\footnotetext{
3 The Kalimah in question is the specific declaration: 'There is none worthy of worship except Allah and Muhammad is the Messenger of Allah'.
} 


\section{A Duty-Based Justificatory Approach}

The alternative justificatory approach I have in mind is not a radical departure from the typical proportionality test. The alternative approach also contemplates 'balancing'. Its main departure from the typical proportionality test is that it seeks to direct the state's justificatory burden towards the demonstration of an individual 'duty of justice' towards others. I imagine such redirection can be done within the parameters of a test that still features proportionality as part of its final limb. The state would simply be required to demonstrate - in the course of meeting the first three limbs of the test - that the individual concerned owes a duty of justice to others. Even when such a duty is demonstrated, the question of proportionality would remain relevant, as the specific means by which the restriction is imposed may be subject to the requirement of proportionality. For example, a duty of justice may ground the state's justification for restricting the public display of obscene material. However, the state is still bound by considerations of proportionality. While it may be proportionate to fine a person for displaying obscene material in a public place, it may be disproportionate to incarcerate that person. Bearing this scheme in mind, I shall argue that a duty-based approach addresses some of the more fundamental normative and political weaknesses associated with the typical proportionality test.

\section{Duties of Justice}

The freedom of expression is an individual liberty. According to the Hohfeldian conception of a 'liberty', which is both widely accepted and conceptually compelling, a liberty can only be constrained by a competing duty that correlates to another's claim right. Not all duties correlate to rights. For instance, imperfect moral duties (Mill 1861) or 'duties of charity' (Goodin 2017) do not correlate to rights. For example, a duty to water a plant on behalf of a neighbour does not correlate to the neighbour's 'right' that the plant is watered (Raz 1986, p. 77). By contrast, an individual's 'duties of justice' are duties that correspond to the rights of others; scholars such as Robert Goodin rightly observe that the state can 'justifiably compel people to perform' such duties (Goodin 2017, pp. 268-271).

Conceptually speaking, duties of justice shape the extent and scope of individual liberty. For example, if $X$ has the liberty to say $\varphi, X$ has no duty of justice to refrain from saying $\varphi$, i.e. no other person has a claim right that $X$ refrains from saying $\varphi$. But if $X$ owes $Y$ a duty to refrain from saying $\lambda, X$ 's freedom of expression does not extend to saying $\lambda$. Only the sphere that is not duty-bound corresponds to $A$ 's freedom of expression. If individual liberty is constrained by competing duties of justice, it follows that an individual's 'liberty' to express something means they do not owe others a duty of justice to refrain from expressing that thing. If an individual owes others a duty of justice to refrain from expressing something, the individual has no liberty to express that thing. In such cases, the state may be justified in restricting the conduct. A duty of justice is, therefore, not the starting point of the reasoning process, but the endpoint. It is the destination one arrives at when one convincingly demonstrates that the competing interests against the conduct in question are important enough to constitute a claim right against the conduct, thereby imposing on the individual concerned a duty of justice to refrain from the conduct. 
What would a duty-based approach to justifying limitations on the freedom of expression look like? The duty-based approach that I have in mind has two features. First, it incorporates the idea of 'public reason' to ensure that only publicly justifiable reasons may be put forward by the state when justifying a limitation on the freedom of expression. This element would necessarily strengthen the legitimacy limb of the proportionality test. Only aims that are publicly justifiable would be considered legitimate, and could form the basis for a limitation on the freedom of expression. Aims that societies cannot find agreement on would not be eligible. For instance, the aim of ensuring 'the glory of Islam' - an aim found in article 19 of Pakistan's Constitution - would not by itself suffice as a legitimate ground on which the freedom of expression can be limited. Similarly, 'secularism', if not an aim shared by many religious minorities in a country, would not in and of itself be valid grounds for limiting the freedom of expression.

Second, the approach I am proposing requires the state to demonstrate a direct responsibility on the part of the individual concerned. This feature of the duty-based approach is consistent with the doctrine of double effect discussed by scholars such as Seana Shiffrin. According to Shiffrin, the double-effect doctrine 'asserts that it may, sometimes, be more permissible to bring about harm as a foreseen or foreseeable but unintended side effect of one's otherwise permissible activity than to bring about equally weighty harmful consequences as an intended means or end of one's activity (emphasis added)' (Shiffrin 2003, pp. 1136-1139). A similar principle is found in tort law, under which 'one would not be held liable for harm...if the harm resulted from deliberate intervention of another agent' (Marmor 2018, p. 153). Individual liberty is ultimately shaped by the 'horizontal' duties the individual concerned owes others (Knox 2008, p. 2). These are horizontal to the extent that one individual owes other individuals, or the community at large, a duty to refrain from engaging in intentional conduct that would cause them harm. Therefore, one's duties of justice are confined to the sphere in which one has direct responsibility for the intended consequences. If, for instance, the violent reactions of others are in fact an intended consequence of the expressive conduct - such as in cases of incitement to violence-it follows that one fails to fulfil a duty of justice to refrain from harming others. Yet if the reactions of others are unintended, it is difficult to maintain that a duty of justice was unfulfilled. One cannot take responsibility for the violent acts of others.

A duty-based justificatory approach is more normatively compelling and politically appealing than a typical proportionality test. The scheme I am proposing addresses the normative weakness associated with the typical proportionality test wherein the special importance we attach to the freedom of expression is often undermined. When certain expressive conduct is presumptively associated with the freedom of expression, the conduct cannot be restricted unless the competing interests at play form a sufficient reason to impose on the individual a duty of justice to refrain from the conduct. The state would need to demonstrate that the individual concerned owes such a duty of justice. A duty of justice, once demonstrated, becomes the placeholder for the publicly justifiable reasons we might have for imposing coercive legal measures against the conduct in question.

The distinction I wish to draw between a duty-based approach and a typical proportionality test can be illustrated as follows. A typical proportionality test would require the state to establish that the interest in the freedom of expression is outweighed 
by the competing interests at play. A duty-based approach simply rejects the idea that a limitation on the freedom of expression can be justified by claiming that the competing interest is weightier than the individual's interest in freedom of expression. The freedom of expression, after all, has special normative value, and should not be merely weighed against competing interests. A duty-based approach requires the state to demonstrate that the competing interests are sufficiently weighty to impose a duty on the individual to refrain from engaging in the expressive conduct in question. This justificatory burden is different to a burden to merely demonstrate that the competing interest is weightier than an interest in the freedom of expression. Instead of asking which interest is weightier, a duty-based justificatory burden requires the state to demonstrate that the competing interest is weighty enough to constitute a claim right (held by others), and a duty of justice (owed by the individual concerned). Under a duty-based approach, the weight of the interest in the freedom of expression is not actually compared with the weight of any competing interest. Instead, specific expressive conduct can be excluded (on the basis of public reason) from the scope of the freedom of expression in view of the fact that the individual concern owes others a duty to refrain from such conduct. This approach retains the normative significance of the freedom of expression instead of subjecting it to consequentialist balancing.

A political case can also be made for adopting a duty-based justificatory approach. Such an approach can place a counter-majoritarian check on state authority to impose limitations on the freedom of expression. A typical proportionality test does not have a specific answer to majoritarian infiltration of interests such as national security, public order, public health, and public morals. It does not have a coherent response to common instances in which majoritarian interests are advanced under the guise of these 'public' interests. It also often fails to contend with cases in which the state seeks to offload its own positive obligations by limiting an individual's freedom of expression. Such offloading is common when members of a majority community violently react to expressions that are unpopular or considered offensive. The state can then use limitation grounds such as 'public order' to limit the individual's freedom of expression for presumably 'causing' the violent reaction, rather than focus on the violent reaction itself.

A duty-based approach to justifying limitations on the freedom of expression makes it more difficult for the state to advance majoritarian interests or offload its positive obligations. For instance, if the competing interest concerns public order, the state would need to demonstrate that the 'public order' interests at stake are actually sufficient reason to constitute a claim right against the expressive conduct in question. It is not at all obvious that an individual merely expressing something offensive owes a duty to refrain from such expression, even when such offence can lead to lawlessnessespecially when the individual does not intend to incite lawlessness. Under a dutybased approach, the competing interests that form the basis of a limitation on the freedom of expression must be sufficient to ground in the individual concerned a duty of justice to refrain from the conduct in question.

An illustration may help explain the political case for the duty-based approach. Let us assume an animal rights activist criticises ritual animal slaughter by the majority religious community in the country. The ritual is considered deeply sacred to the customs of the majority community, and the criticism outrages a number of those belonging to the community. There are subsequent calls to arrest the activist and ban 
such criticism. The state takes no action at first, and as a result, several members of the majority community engage in violent and disruptive protests in public spaces. The state initially arrests some of the perpetrators, but also decides to prohibit the activist and others from engaging in any further criticism of ritual animal slaughter. It justifies the prohibition on the basis that the impugned conduct, i.e. the criticism of animal slaughter, 'causes' others to engage in violent and disruptive behaviour, which impairs public order. The state may articulate its justification for the limitation in the following manner: others have an interest in public order, and if certain criticism directly causes persons to engage in acts of public disorder, the state is justified in restricting such criticism. There is no doubt that the interest in public order is important. Such an interest, for instance, grounds a positive obligation in the state to prevent violent and disruptive behaviour. Individuals meanwhile have duties to refrain from such behaviour. But at no point is it apparent that an individual engaging in contentious and unpopular criticism owes a duty of justice (i.e. a duty that directly corresponds to the claim rights of others) to refrain from such criticism - even if such criticism appears to have 'caused' others to react violently. A typical proportionality test does not confront this problem, as it does not necessarily require the state to deal with intentionality when limiting the freedom of expression. It would only require the adjudicative body to weigh the individual's interest in the freedom of expression against the interests of others in public order; a restriction on such criticism could conceivably be justified if the court or tribunal decided that the competing interests outweighed the interest in the freedom of expression. The state's intention to appease a majority community, or offload its positive obligations, may very well go unchecked.

A duty-based approach directs the state to demonstrate an individual duty of justice, which necessarily incorporates public reason, and the direct responsibility of the individual. In terms of the illustration concerning ritual animal slaughter, to say that interests in public order are publicly justifiable reasons to restrict an activist's criticism seems unreasonable, as it ignores the fact that it is someone else's conduct and not the activist's conduct that actually results in setbacks to public order. Therefore, the state would need to do much better to demonstrate that the activist concerned owes others a duty of justice to refrain from criticising animal slaughter if a limitation on the activist's freedom of expression in that respect was to be justified. The state is then, to some extent, prevented from offloading its positive obligation (to prevent public disorder) onto the activist. This is the fundamental political value of a duty-based justificatory approach. It is not only a more normatively compelling approach, wherein the special importance of the freedom of expression is better preserved; it is also a politically appealing approach, as it requires the state to justify a limitation on the freedom of expression based on the specific horizontal relationship that exists between the individual and others in society.

\section{Is the Language of Duties Dangerous?}

The language of duties can be hijacked by those seeking to diminish the scope of rights. It is therefore natural for the language of duties to attract scepticism and suspicion. For example, the 'Asian values' project advanced by political actors such as former Singaporean Prime Minister Lee Kuan Yew relied on a language of 'duties' (among other terms such as 'obedience' and 'loyalty') as a means of deflecting concern for 
human rights (Sen 1997). Moreover, in 2007 and thereafter, the UK witnessed a surge in interest among political actors to frame a new bill of 'rights and duties'. The discourse enabled some political actors to call for the replacement of the UK's Human Rights Act of 1998 with a new bill that focuses both on individual rights and responsibilities. It is therefore natural for the language of duties to attract scepticism and suspicion. But as pointed out by Samuel Moyn, 'the need to guard against destructive ideas of duty is a poor excuse for ignoring beneficial liberal ones' (Moyn 2016, p. 11).

Despite the obvious risks, adopting the language of duties to describe a more robust justificatory approach is valuable, both for methodological and ethical reasons. First, it is not possible to articulate each and every 'claim right' in terms of well-recognised 'human rights'. A person's claim right that another person refrains from doing something specific cannot always be articulated as a 'human right'. For instance, a person's claim right that another person refrains from causing public unrest is certainly a 'claim right', but cannot easily be framed in terms of a specific 'human right' found in, say, the ICCPR or ECHR. By contrast, it can easily be framed as an interest that both these treaties recognise - 'public order'. A person's interest in public order, in certain circumstances, is sufficient reason to impose on another person the duty to refrain from expressive conduct that could directly harm that interest. In such circumstances, that person would have a claim right and the other would have a duty of justice to refrain from such conduct. Framing the state's burden to justify the limitation in terms of 'rights' could lead to confusion, as it may prompt us to look for a 'human right'. Instead, the relevant 'claim right' is contingent on the outcome of a reasoning process whereby the importance of the public order interest, in the specific circumstances under consideration, is sufficient reason to impose on an individual a duty to refrain from conduct that directly impairs the interest. This justificatory approach may be better described as a 'duty-based' approach because the outcome of the reasoning process is the demonstration of an individual duty of justice to refrain from engaging in the conduct in question.

Second, there is an ethical benefit to reclaiming the language of duties. Such language can help individuals make ethical sense of how their expressive conduct impacts others. David Petrasek correctly observes that the language of duties introduces a certain 'global ethic' to modern human rights discourse (Petrasek 1999, p. 7), which is currently missing. Moyn poignantly notes: 'Human rights themselves wither when their advocates fail to cross the border into the language of duty' (Moyn 2016, p. 10). Such language can then 'instil in individuals the idea that they should act in ways that support basic shared values' (Petrasek 1999, p. 48), and motivate them to be more aware of their ethical obligations to others. Framing a limitation only as a means of advancing legitimate interests, or relying purely on the language of proportionality, cannot offer this ethical dimension. Therefore, the risks associated with the language of duties are ultimately outweighed by its methodological and ethical benefits.

\section{Conclusion}

In this article, I evaluated a typical proportionality test when applied to cases concerning limitations on the freedom of expression, and discussed some of the 
normative and political weaknesses associated with the test. I presented a case for an alternative approach that places duties of justice at the centre of the state's burden to justify limitations on the freedom of expression. This alternative approach does not completely discard the proportionality test; it instead attempts to address some of the weaknesses of the test. I termed this alternative approach a 'duty-based justificatory approach' for certain methodological and ethical reasons. I argued that, when individual conduct concerns the freedom of expression, the state's burden to justify the restriction on such conduct must involve demonstrating that the individual concerned owes others a duty of justice to refrain from engaging in the conduct.

Once we fully appreciate the value of the freedom of expression, we begin to see the sense in requiring the state to demonstrate a duty of justice when justifying limitations on the freedom of expression. Such an approach is normatively valuable, as it better sustains the normative primacy and peremptory value of the freedom of expression. The state would need to compellingly demonstrate that the various interests that compete with the individual's interest in the freedom of expression are sufficient reason to impose a duty of justice on the individual concerned. It would have to rely on public reason to demonstrate such a duty, and it would ultimately have to prove that the individual concerned has a direct responsibility for any harmful consequences emanating from the conduct in question. Apart from such normative value, we have seen that a duty-based approach can be politically valuable. It places a clearer burden on the state to demonstrate how the individual concerned directly owes a duty of justice to others to refrain from engaging in the impugned conduct. The state is accordingly constrained from advancing certain majoritarian interests, or offloading its positive obligations by limiting the individual's freedom of expression.

There appears to be a compelling normative and political case to place duties of justice at the centre of the state's burden to justify limitations on the freedom of expression. Such an approach would not radically depart from the proportionality test, which retains its place as a 'core doctrinal tool' (Möller 2014, p. 31) to determine the permissibility of limitations on the freedom of expression. The alternative approach I have proposed instead adds crucial scaffolding to the typical proportionality test. It sets out to reinforce the state's burden to confine itself to the realm of public reason, and insists that the state demonstrates that the individual concerned owes others a duty of justice to refrain from the impugned conduct. Such an approach would enhance the state's justificatory burden when it seeks to limit one of our most cherished values: the freedom of expression.

Acknowledgements The author wishes to thank Dr Nazila Ghanea, Dr Godfrey Gunatilleke, Tom Kohavi, Shamara Wettimuny, and Wijith de Chickera for their generous time in reviewing previous versions of this article, and for their valuable feedback.

Open Access This article is licensed under a Creative Commons Attribution 4.0 International License, which permits use, sharing, adaptation, distribution and reproduction in any medium or format, as long as you give appropriate credit to the original author(s) and the source, provide a link to the Creative Commons licence, and indicate if changes were made. The images or other third party material in this article are included in the article's Creative Commons licence, unless indicated otherwise in a credit line to the material. If material is not included in the article's Creative Commons licence and your intended use is not permitted by statutory regulation or exceeds the permitted use, you will need to obtain permission directly from the copyright holder. To view a copy of this licence, visit http://creativecommons.org/licenses/by/4.0/. 


\section{References}

\section{Books, Chapters, and Articles}

Arai-Takahashi Y (2002) The Margin of Appreciation Doctrine and the Principle of Proportionality in the Jurisprudence of the ECHR. Intersentia, Cambridge

Arai-Takahashi Y (2005) Scrupulous but Dynamic'-the Freedom of Expression and the Principle of Proportionality under European Community Law. Yearbook of European Law 24(1): 27-79

Barak A (2012) Proportionality: Constitutional Rights and Their Limitations. Cambridge University Press, Cambridge

Berlin I (1969) Two Concepts of Liberty. In Isaiah Berlin, Four Essays on Liberty. Oxford University Press, Oxford

Boyle K and Shah S (2014) Thought, Expression, Association and Assembly. In: Moeckli D, Shah S, Sivakumaranm S, and Harris D (eds) International Human Rights Law. Oxford University Press, Oxford

Choudhry S (2006) So What Is the Real Legacy of Oakes? Two Decades of Proportionality Analysis under the Canadian Charter's Section 1. Supreme Court Law Review 34: 501-535

Dworkin R (1977) Taking Rights Seriously. Harvard University Press, Cambridge, MA

Dworkin R (1984) Rights as Trumps. In: Waldron J (ed) Theories of Rights: Oxford Readings in Philosophy. Oxford University Press, Oxford

Dworkin R (1985) A Matter of Principle. Harvard University Press, Cambridge, MA

Feinberg J (1970) The Nature and Value of Rights. The Journal of Value Inquiry 4(4): 243-260

Feinberg J (1987) The Moral Limits of the Criminal Law Volume 1: Harm to Others. Oxford University Press, Oxford

Gaus GF (1996a). Justificatory Liberalism: An Essay on Epistemology and Political Theory. Oxford University Press, Oxford

Gaus GF (1996b) Liberalism, Stanford Encyclopaedia of Philosophy (revised version as of 22 January 2018) George RP (1995) Making Men Moral: Civil Liberties and Public Morality. Oxford University Press, Oxford Goodin RE (2017) Duties of Charity, Duties of Justice. Political Studies 65(2): 268-283

Grimm D (2007) Proportionality in Canadian and German Constitutional Jurisprudence. University of Toronto Law Journal 57: 383-397

Hart HLA (1955) Are There Any Natural Rights? The Philosophical Review 64(2): 175-191

Hohfeld WN (1919) Fundamental Legal Conceptions as Applied in Judicial Reasoning. Cook WW (ed). Yale University Press, New Haven

Khan AM (2015) Pakistan's Anti-Blasphemy Laws and the Illegitimate use of the 'Law, Public Order, and Morality' Limitation on Constitutional Rights. The Review of Faith \& International Affairs 13(1): 13-22

Knox JH (2008) Horizontal Human Rights Law. The American Journal of International Law 102(1): 1-47

Kumm M (2004) Constitutional rights as principles: On the structure and domain of constitutional justice. International Journal of Constitutional Law 2(3): 574-596

Kumm M (2010) The Idea of Socratic Contestation and the Right to Justification: The Point of Rights-Based Proportionality Review. Law \& Ethics of Human Rights 4: 142-175

Letsas G (2007) A Theory of Interpretation of the European Convention on Human Rights. Oxford University Press, Oxford

Letsas G (2006) Two Concepts of the Margin of Appreciation. Oxford Journal of Legal Studies 26(4): 705732

Marmor A (2018) Two Rights of the Freedom of Expression. Ratio Juris 31: 139-159

Mill JS (1859) On Liberty

Mill JS (1861) Utilitarianism. In: The Collected Works, Volume 10 (1974), University of Toronto Press, Toronto

Möller K (2014) Constructing the Proportionality Test: An Emerging Global Conversation. In: Lazarus L, McCrudden $\mathrm{C}$ and Bowles N (eds) Reasoning Rights: Comparative Judicial Engagement. Hart Publishing, London

Moyn S (2016) Rights vs. Duties: Reclaiming Civic Balance. Boston Review 41(3): 1-12

O’Neill O (1996) Towards Justice and Virtue: A Constructive Account of Practical Reasoning. Cambridge University Press, Cambridge

Petrasek D (1999) Taking Duties Seriously: Individual Duties in International Human Rights Law - A Commentary. International Council on Human Rights Policy, Versoix

Rawls J (1999). A Theory of Justice: Revised Edition. Harvard University Press, Cambridge, MA 
Rawls J (2005) Political Liberalism: Expanded Edition. Columbia University Press, New York

Raz J (1986) The Morality of Freedom. Clarendon Press, Oxford

Raz J (1999) Practical Reason and Norms. Oxford University Press, Oxford

Rivers J (2006) Proportionality and Variable Intensity of Review. Cambridge Law Journal 65: 174-207

Scanlon T (1998) What We Owe to Each Other. Belknap Press, Cambridge, MA

Sen A (1997) Human Rights and Asian Values: What Lee Kuan Yew and Li Peng don't understand about Asia. The New Republic 217 (2-3): 33-40

Shiffrin S (2003) Speech, Death, and Double Effect' New York University Law Review 78(3): 1135-1185

Stone GR (1987) Content-Neutral Restrictions. University of Chicago Law Review 54: 46-118

Strauss DA (2002) Freedom of Speech and the Common-Law Constitution. In: Bollinger LC and Stone GR (eds) Eternally Vigilant: The Freedom of Expression in the Modern Era, University of Chicago Law Press, Chicago

Tremblay LB (2014) An egalitarian defense of proportionality-based balancing. International Journal of Constitutional Law 12 (4): 864-890

Tridimas T (2007) The General Principles of EU Law. Oxford University Press, Oxford

Tsakyrakis S (2009) Proportionality: An Assault on Human Rights? International Journal of Constitutional Law 7: 468-493

Urbina FJ (2015) Incommensurability and Balancing. Oxford Journal of Legal Studies 35 (3): 575-605

Urbina FJ (2014) Is it Really That Easy? A Critique of Proportionality and 'Balancing as Reasoning'. Canadian Journal of Law \& Jurisprudence 27 (1): 167-192

Van Dijk P and Van Hoof GJH (1998) Theory and Practice of the European Convention on Human Rights. 3rd edition. Kluwer, The Hague

Von Bernstorff J (2014). Proportionality Without Balancing: Why Judicial Ad Hoc Balancing is Unnecessary and Potentially Detrimental to the Realisation of Individual and Collective Self Determination. In: Lazarus L, McCrudden C and Bowles N (eds) Reasoning Rights: Comparative Judicial Engagement. Hart Publishing, London

Waldron J (1993). Liberal Rights. Cambridge University Press, Cambridge

Webber G (2009) The Negotiable Constitution: On the Limitation of Rights. Cambridge University Press, Cambridge

Zoller E (2009) The United States Supreme Court and the Freedom of Expression. Indiana Law Journal 84: 885-916

Zysset A (2019) Freedom of expression, the right to vote, and proportionality at the European Court of Human Rights: An internal critique. International Journal of Constitutional Law 17(1): 230-251

\section{Cases}

Claudia Andrea Marchant Reyes et al. v. Chile, Communication No 2627/2015 (CCPR views adopted on 7 November 2017), CCPR/C/121/D/2627/2015

Fedotova v. The Russian Federation, Communication No 1932/2010 (CCPR views adopted on 31 October 2012), CCPR/C/106/D/1932/2010

Handyside v. The United Kingdom, Application No. 5493/72, ECtHR judgment of 7 December 1976

I.A. v. Turkey, Application no. 42571/98, ECtHR judgment of 13 December 2005)

Ladue v. Gilleo (1994) 512 U.S. 43 (U.S. Supreme Court)

Leyla Şahin v. Turkey, Application No 44774/98, ECtHR judgment [GC] of 10 November 2005

Otto-Preminger-Institut v. Austria, Application No. 13470/87, ECtHR judgment of 20 September 1995

$R$ v. Oakes [1986] 1 SCR 103 (Canadian Supreme Court)

S.A.S v. France, Application No 43835/11, ECtHR judgment [GC] of 1 July 2014)

Thoma v. Luxembourg, Application No 38432/97, ECtHR judgment of 29 June 2001

United States v. O'Brien (1968) 391 U.S. 367 (U.S. Supreme Court)

Wingrove v. The United Kingdom, Application No. 17419/90, ECtHR judgment of 25 November 1996

Zaheeruddin v. State (1993) SCMR 1718 (Supreme Court of Pakistan)

Publisher's Note Springer Nature remains neutral with regard to jurisdictional claims in published maps and institutional affiliations. 